\title{
YELLOW FEVER EPIZOOTICS IN NON-HUMAN PRIMATES, SÃO PAULO STATE, BRAZIL, 2008-2009
}

\author{
Eduardo Stramandinoli MORENO(1,2), Roberta SPINOLA(2), Cilea Hatsumi TENGAN(2), Roosecelis Araujo BRASIL(3), Melissa Mascheratti SICILIANO(2), \\ Terezinha Lisieux Moraes COIMBRA(3), Vivian Regina SILVEIRA(3), Iray Maria ROCCO(3), Ivani BISORDI(3), Renato Pereira de SOUZA(3), \\ Selma PETRELla(3), Luiz Eloy PEREIRA(3), Adriana Yurika MAEDA(3), Fernanda Giselle da SILVA(3) \& Akemi SUZUKI(3)
}

\begin{abstract}
SUMMARY
Since 2000, the expansion of Sylvatic Yellow Fever (YF) has been observed in the southeast of Brazil, being detected in areas considered silent for decades. Epizootics in non-human primates (NHPs) are considered sentinel events for the detection of human cases. It is important to report epizootic events that could have impact on the conservation status of susceptible species. We describe the epizootics in NHPs, notified in state of São Paulo, Brazil, between September 2008 to August 2009. Ninety-one epizootic events, involving 147 animals, were reported in 36 counties. Samples were obtained from 65 animals (44.2\%). Most of the epizootics (46.6\%) were reported between March and April, the same period during which human cases of YF occurred in the state. Biological samples were collected from animals found dead and were sent to Instituto Adolfo Lutz, in São Paulo. Two samples, collected in two counties without an indication for YF vaccination, were positive for the virus. Another 48 animals were associated with YF by clinicalepidemiological linkage with laboratory confirmed cases. Because the disease in human and NHPs occurred in the same period, the detection of the virus in NHPs did not work as sentinel, but aided in the delineation of new areas of risk.
\end{abstract}

KEYWORDS: Epizootics; Non-human primates, Yellow fever, Howler monkey.

\section{INTRODUCTION}

The Non Human Primate (NHP) species diversity on the Neotropics is currently estimated at 199 species and sub-species ${ }^{32}$. According to a IUCN (International Union for Conservation of Nature) list of threatened species $^{19}, 40$ out of 56 species of the Platyrrhini parvorder that exist in $\mathrm{Brazil}^{3}$, are listed as vulnerable, threatened or critically threatened. The main conservational threats faced by these NHP species, includes: loss and fragmentation of the habitat, predatory hunting and illegal wildlife trade $^{3}$.

Although no primate species is included in the list of 54 mammal species that have infectious diseases as the greatest threat for their conservation, outbreaks have impacted NHP populations in several regions of the world ${ }^{3,10,15,35}$, especially in Panama, Trinidad and Tobago, Colombia and Brazil. Historical evidences in Central and South America support the idea that NHP populations have been severely affected by Yellow Fever (YF) epizootics $3,3,31$. Moreover, the presence of antibodies against YF, in wildlife NHPs seems to be a relatively common finding ${ }^{20,36}$. NHPs are considered sylvatic hosts of the yellow fever virus (YFV) in Africa and in the Americas.

In the African continent, NHPs seem to be more resistant to virus infection and are rarely threatened by the disease ${ }^{36}$. This may allow the quick renewal of the NHP population, facilitating the maintenance of the virus in the area and shortening inter-epidemic periods ${ }^{5,36}$.

All neotropical NHP species are susceptible to the disease. Serological responses, clinical illnesses and spontaneous deaths are described in the Alouatta spp., as well as, in Callitrichidae and Pitheciidae species ${ }^{1,14,27,29,30}$. The primates of Aotus genus are susceptible too, but due to their nocturnal habits, they have limited exposure to the virus ${ }^{27}$. The genera Cebus, Sapajus, Ateles and Saimiri, have been shown to be more resistant, although RICHTER et al. ${ }^{30}$ have reported severe illness in Saimiri.

In the Amazon region, where the YF is considered endemic, the disease shows a cyclic dynamic, causing outbreaks in humans and NHPs at intervals varying between seven and fourteen years ${ }^{8}$. According to some authors ${ }^{13,36}$, this interval would be the time required for the renewal of the susceptible NHP populations.

The occurrence of sylvatic yellow fever (SYF) in Brazil, was restricted, until 2000, to the North and Middle-West regions of the country ${ }^{23,24}$. However, in the outbreaks that occurred in 2000/2003 period, a geographic expansion of YFV to the southeast was observed and detected in areas previously free from its circulation for decades, thus forcing a redefinition of risk areas ${ }^{26}$. 


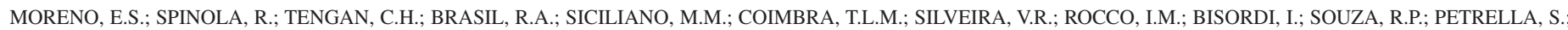
PEREIRA, L.E.; MAEDA, A.Y.; SILVA, F.G. \& SUZUKI, A. - Yellow fever epizootics in non-human primates, São Paulo State, Brazil, 2008-2009. Rev. Inst. Med. Trop. Sao Paulo, 55(1): 45-50, 2013.

More recently, in 2008-2009, outbreaks of the disease were detected in the Brazilian states of São Paulo ${ }^{18,25,26}$, Paraná ${ }^{25}$ and Rio Grande do $\mathrm{Sul}^{25}$, affecting both humans and NHPs. Twenty-eight autochthonous human cases were detected, in the state of São Paulo, between 2008 and $2009^{13,18,25,26}$. The disease has also been identified in NHPs in the Province of Missiones, Argentina ${ }^{14}$.

Epizootic events involving YF are considered sentinel for the detection of human cases of the disease. The Brazilian Ministry of Health created the Non-Human Primates Epizootic Events Surveillance System in 1999, which was incorporated into the Yellow Fever Surveillance System $^{23}$. This system was established in the state of São Paulo in 2003 and detected the first epizootic event caused by YF in February, $2008^{26}$.

The lack of information on the impact of infectious diseases on NHP populations, and the rising threats for Brazilian NHP species, stresses the importance of reporting these events. The purpose of this paper is to describe the epizootics, reported to the NHP Epizooties Surveillance System in the state of São Paulo, between September 2008 till August 2009 , and, also to show how this analysis was important for supporting an evidence-based public-health decision-making process to guide actions in YF outbreak emergency situations. The article also discusses the possible role played by different primate species in the eco-epidemiology of YF in Brazil.

\section{MATERIALS AND METHODS}

Study Area: The study was conducted in the state of São Paulo, Brazil, which is composed of 645 counties, occupies an area of approximately $248,196,960 \mathrm{~km}^{2}$, and has 41,262,199 inhabitants, concentrated mainly in the coastal zone ${ }^{16}$. Currently, the state has 429 counties situated in the endemic area for YF and 216 in the nonendemic one. This is a descriptive study encompassing events between September 2008 and August 2009. The NHPs death notifications to the Non Human epizootics Surveillance System / Public Health Department from the state of São Paulo, were used as database. The notifications were spontaneously made by the resident population to the municipal epidemiological surveillance authorities that provided a technician for the collection of biological samples, when possible.

Case definitions: The case definitions were created following the Guide for Surveillance of Epizootics in Non-Human Primates/Brazil Ministry of Health ${ }^{23}$.

YF suspected cases or suspected epizootic events: Any event involving death (including skin and bones found) or clinical illness, of at least one non human primate, whose cause was inconclusive, in any part of the state of Sao Paulo.

YF laboratorial confirmed cases: Suspected cases that showed positive laboratorial results for YF, by any of the laboratorial techniques cited in the study.

YF confirmed cases by clinical-epidemiological linkage: Suspected cases, whose sample collection was not possible, found within a radius of $30 \mathrm{~km}$ from a place with laboratorial confirmed YFV circulation up to within 30 days of a YF confirmed event.
Sample collection: Monkeys found dead, but still in a suitable state of preservation for the study, were submitted to necropsy for the removal of liver, spleen, kidney, heart, lung, and intra-cardiac blood. The samples were sent to Instituto Adolfo Lutz, in Sao Paulo County. Animals found in an advanced level of autolysis (longer than 24 hours after death) were excluded from the study.

Laboratory diagnosis: All samples were analyzed by one or more of these methods: virus isolation (in mice and/or cell culture), indirect immunofluorescence, RT-PCR and sequencing, histopathology, and immunohistochemistry.

Virus isolation in mice: Samples of blood, and tissues were inoculated for isolation of the virus in Swiss mice, 1-3 days old. Samples of liver and brain were inoculated separately, and the other viscera were processed in a mixed suspension. The tissues were macerated, suspended in a solution of bovine albumin, $0.75 \%$, with antibiotics $(100 \mu \mathrm{g} / \mathrm{mL}$ of streptomycin and $100 \mathrm{UI} / \mathrm{mL}$ of penicillin) and centrifuged at 6,000 rpm for 20 minutes. $0.02 \mathrm{~mL} / \mathrm{mouse}$ of each suspension was inoculated by the intracerebral route in six suckling mice. Blood samples or serum were inoculated separately, pure or diluted $(50 \%)$ in albumin solution. The animals were observed for 14 days.

Virus isolation in cell culture: The same suspensions of tissues for inoculation in mice, in addition to blood and serum, were also subjected to isolation of the virus in Aedes albopictus cell culture, clone $\mathrm{C} 6 / 36^{17}$, and indirect immunofluorescence assay (IFA), following the technique standardized by GUBLER et al. ${ }^{12}$. Polyclonal anti-yellow fever antibodies, prepared in mice and anti-mouse immunoglobulin combined and marked with fluorescein isothiocyanate (Sigma), were used. The positive samples were identified by IFA with YFV monoclonal antibodies (Biomanguinhos-RJ)).

RNA extraction and RT-PCR: Total RNA was extracted using commercial kits. For tissue fragments the QIAamp ${ }^{\circledR}$ RNA Blood (Qiagen Inc., Ontario, CA) was used, and for serum, the QIAamp ${ }^{\circledR}$ Viral RNA Kit (Qiagen Inc., Ontario, CA) was used, following the manufacturer's instructions. The amplification of viral RNA was performed by one-step reverse transcriptase (RT-PCR), followed by a second amplification $(\text { semi-nested })^{9}$ from the products of the first reaction, diluted at 1:50. The amplified products were visualized by electrophoresis in $1.5 \%$ agarose gel stained with ethidium bromide. Positive samples were those that had a band compatible with the expected.

Sequencing: The positive samples were sequenced directly on an ABI 377 sequencer by method of termination dideoxy cycle sequence, using the BigDye Terminator sequencing kit v.3.1 (Applied Biosystems, Foster City, CA), following the instructions recommended by the manufacturer with the same pair of primers of RT-PCR reaction in one step. For the edition of the nucleotide sequences, Chromas EditSeq 1.45 software (Lasergene DNAStar Inc.) was used, excluding the sequences of primers.

Histopathology and Immunohistochemistry: Viscera samples to be used for a pathological and immunohistochemical studies, were subjected to histological procedures for paraffin inclusion. Slides with histological sections obtained from specimens were submitted to histological (by hematoxylin-eosin staining) and immunohistochemical analysis. For 


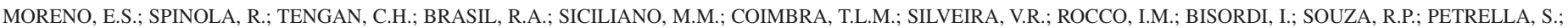

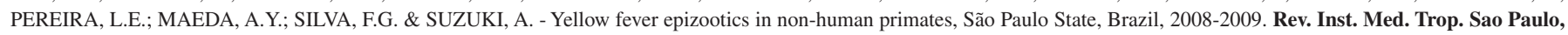
55(1): 45-50, 2013.

the immunohistochemical investigation of viral antigen, the polyclonal anti-YFV antigen amplified in reaction with the polymer-conjugated enzyme (EnvisionTM System- HRP, Dako Cytomation, USA) was used and revealed with diaminobenzidine ${ }^{6,33}$.

Epidemiological analysis: The cases were described according to time, place and species/genus. Geographic clusters of cases were analyzed separately.

Expansion of YF vaccination area: All municipalities that had identified confirmed cases of YF in NHP passed through a vaccination campaign of the human population. Municipalities located inside in a radius of $30 \mathrm{~km}$ of municipalities with confirmed cases for YF were also included in the campaign.

\section{RESULTS}

Ninety-one epizootic events (suspected cases) were registered during the study period, amounting to 147 animals, distributed in 36 different counties. Figure 1 shows the frequency of notifications per month.

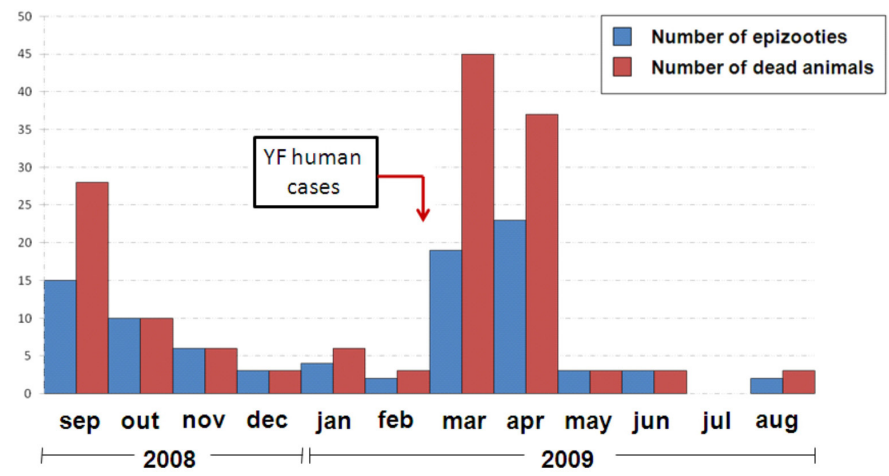

Fig. 1 - NHPs epizootics notified distribution per month. September 2008, August 2009, São Paulo State, Brazil.

It is observed that the largest number of reported epizootics occurred in March and April, 2009, the same period when 28 human cases were confirmed in the State (Fig. 1).

At least, one type of sample from each of the $66(45 \%)$ NHPs was collected; 57 (39\%) had organ fragments collected, 39 (27\%) had blood samples taken and $20(14 \%)$ had brain samples collected.

Among all the animals stated, 67 (45\%) were Alouatta spp., 58 (39\%) Callithrix spp., 15 (10\%) Sapajus spp. and 7 (6\%) of other genus.

Figure 2 shows the geographical distribution of the suspected epizooties notified. Two main geographic clusters of notifications could be observed - one situated in the north of the State, in an area with indication for YF vaccination, and the other one in the south, in a region without any indication for YF vaccination until 2009.

Figure 3 shows the epidemic curves of YF notifications for these two clusters. In the cluster area without YF vaccination until 2009, two epizootic events were laboratorially confirmed for YF. The first one was positive by RT-PCR and virus isolation in mice, from a blood sample

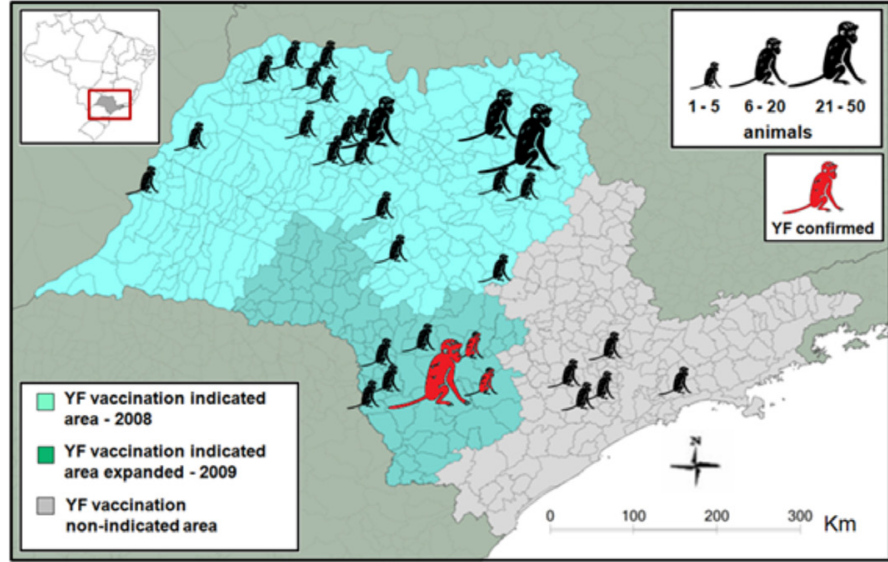

Fig. 2 - Geographical distribution of NHPs YF suspected epizooties notified. São Paulo State Brazil, September 2008 to August 2009

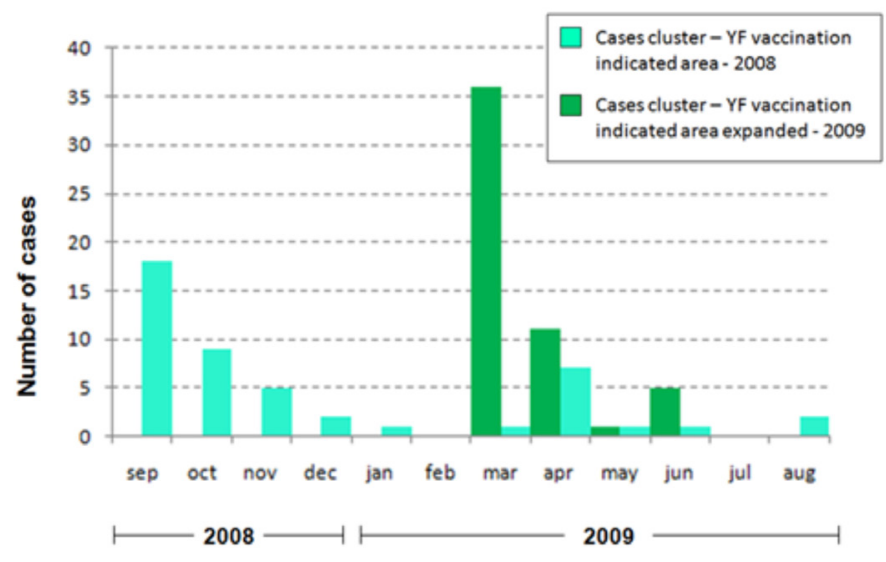

Fig. 3 - Distribution of two main clusters of NHPs epizooties considered suspected cases of YF per month. São Paulo State, Brazil, September 2008 to August 2009.

taken from one animal. Another 45 animals were related, geographically and temporally, to this event and case confirmation was made by clinical-epidemiological linkage. The second one was confirmed by a immunohispathological test, performed on a pool of visceral organs of one animal. Another three animals were related, geographically and temporally to this event. In this case, confirmation was carried out using clinical-epidemiological linkage. All 50 YF confirmed animals were of Alouatta spp. genus.

These epizootics enabled the delineation of the new expanded YF vaccination indicated area in the State (Fig. 2), within the YF human cases surveillance system as well as eco-epidemiological evaluations. In total, 49 counties were included in the YF risk area and more than one million people in the region were vaccinated by the end of 2009.

\section{DISCUSSION}

The collection of biological samples and the identification of NHP species are limiting factors for surveillance since such events are dependent on the availability of trained technicians, who oftentimes cannot be available. This demonstrates the need for the periodic 


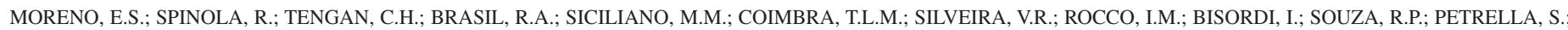
PEREIRA, L.E.; MAEDA, A.Y.; SILVA, F.G. \& SUZUKI, A. - Yellow fever epizootics in non-human primates, São Paulo State, Brazil, 2008-2009. Rev. Inst. Med. Trop. Sao Paulo, 55(1): 45-50, 2013.

capacitation on primatology for health professionals involved with sample collection in the NHP epizootics surveillance system. This type of information would permit important conclusions about the role of each species on the eco-epidemiology of YF, as well as the impact of the disease in these populations.

Studies strongly rely on epidemics being disclosed by a local rural population, since the notifications are made by them. People who have experienced epidemics of YF in their regions in the past, are more sensitive to these events ${ }^{3}$. However, results do not represent all NHP deaths in the State.

The two main geographic clusters of epizootic events showed two distinct moments for NHP epizootics surveillance in the state of São Paulo. Cluster A was situated in the North of State. This region has had YF vaccination indicated since 1986 with good vaccine coverage ${ }^{26}$. In the beginning of 2008, YF cases were registered in NHPs and humans in the region, and so the vaccination campaigns were intensified. This study period coincides with the first rainy season after which higher occurrences of YF are expected ${ }^{36}$.

Thus, despite the geographic clustering of NHP death notifications in the region, they were distributed evenly and in low levels during the period studied, characterizing a non epizootic behavior. Notifications from this geographical cluster registered three different genera of NHPs: Callithix spp., Sapajus spp. and Allouatta spp. However, no sample had positive results for YFV.

Cluster B was located in the southwestern region of the State. The region had not had a vaccination program against YF prior to March 2009. An increase in the number of notifications, geographic and temporally clustered, was detected affecting individuals of the same genus (Howler monkey - Alouatta spp.), in a short period of time, thus characterizing an epizootic behavior.

In this cluster only Alouatta deaths were notified. The same genus was also shown in studies conducted in other parts of Brazil ${ }^{3,11}$ as well as in the north of Argentina ${ }^{14}$ in the same period.

Howler monkeys are distributed in neotropical regions, and are reported from the state of Vera Cruz in Mexico to the state of Rio Grande do Sul in Brazil, and Corrientes in Argentina ${ }^{11}$. In São Paulo State the two species of howler monkeys most commonly registered are: A. caraya and A. clamitans.

A. caraya occurs in the north and northwest regions in areas composed of savanna-like vegetation while A. clamitans occurs particularly in the south, southeast and coastal zones of the state in areas composed of rainforest vegetation. The lack of information about the size of Alouatta spp. populations in the state makes it difficult to estimate the YF impact for this species in the region.

Studies such as this present one raise the discussion of the role of the impact of emerging infectious diseases on population dynamics of its sylvatic hosts, mainly if they are a threatened species, which can potentially cause secondary effects in the whole ecosystem ${ }^{2,22}$.

In simple parasite-hosts systems, the pathogens would not cause the extinction of their hosts, because over time the virulence of the pathogens is expected to attenuate ${ }^{2}$. If this attenuation does not take place, the population of the host can be reduced to very low levels.

Alternatively, a pathogen can lead to the extinction of a host. In this case, its impact reduces the host's population to such low levels that it makes it vulnerable to stochastic events ${ }^{21}$.

The prevalence of diseases transmitted by vectors, such as YF, with a wide range of host species is less dependent on a hosts density than on its diversity. The presence of many possible reservoir species (wild mosquitoes of genus Haemagogus spp. and Sabhetes spp. $)^{4}$, or hosts species with different levels of susceptibility (Sapajus spp., Callitrhix spp., Allouatta spp., Homo sapiens) can increase the environmental viral charge and be a source of infection for sensitive species.

The dilution effect can explain this system. This effect is reached when, in a given place, vertebrate host species with low capacity of infect their vectors share the same environment, diluting the effect of highly competent reservoir species ${ }^{34}$. For YFV, the contribution of each species potentially involved in its epidemiological cycle is not totally known. The combination of different species in a certain area makes it possible for different capacities to increase the viral load level in the environment.

Moreover, it is known that fragmented environments tend to posse less species diversity, potentially leading to a reduction in the dilution effect for viruses such as YFV. This fragmentation can lead to a further increase of the rate of encounters among pathogenic agents and their reservoirs, vectors and host species. As a consequence, there is an increase in environmental agent charge in a reduced space of time, which works as a catalyst for this system. This would favor the occurrence of more explosive outbreaks in sensitive populations, which is particularly the case with Howler monkeys.

Species of the Sapajus spp. genus are easily infected by YFV. However, they show low rates of lethality as, in general, this species acquires immunity. In laboratory conditions, they respond to YFV inoculation with two to six days of viremia. They can serve as blood meals for mosquitoes for a considerable period of time thus suggesting an amplificatory role of these species in the YFV cycle ${ }^{13}$.

Due to a high sensibility and susceptibility to the infection with YFV, Howler monkeys succumb quickly to the disease, presenting an extremely acute pattern ${ }^{1,14,27,28,30}$. Considering the reduced time of viremia and exposure to vectors, they can be considered as the final hosts of the disease.

Humans, with an incidence rate of asymptomatic cases that can reach up to $70 \%{ }^{34,36}$, could have a more important role as YFV amplifier hosts than NHP primate species in some regions affected by $\mathrm{YF}^{34}$. As a result, the vaccination of human populations, that surround areas with known susceptible populations of Howler monkeys, could have some impact in the conservation of these species.

Although these epizootic events didn't work as sentinel for the detection of YF human cases in the studied region, they were an important tool for the redefinition of the area of YF risk in the state. The NHP Epizootic Surveillance System also contributed indirectly 


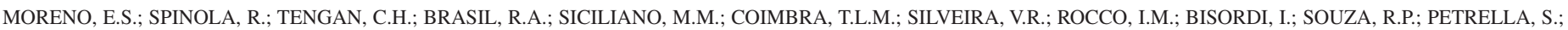

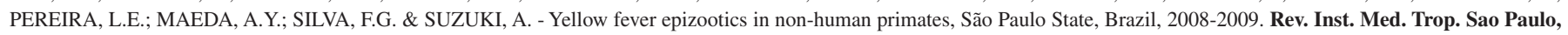
55(1): 45-50, 2013.

to our knowledge about the distribution of NHPs species in São Paulo State, Brazil, as well as to the potential impact of YF in Howler monkey populations in Brazil. In conclusion, Yellow fever caused at least two epizootic events affecting 50 animals of Alouatta spp. genus in São Paulo State, Brazil, in the period between September 2008 and August 2009. The Non Human Primate Epizootic Surveillance System was shown to be an important tool for the YF control, being vital in defining risk areas and identifying human and NHP vulnerable populations. The paper also demonstrated the importance of descriptive epidemiology supporting an evidence-based public-health decision-making process to guide actions in YF outbreak emergency situations.

\section{RESUMO}

\section{Epizootias de febre amarela em primatas não humanos no estado de São Paulo, Brasil, 2008-2009}

Desde 2000, vem sendo observada a expansão da febre amarela (FA) no Sudeste do Brasil, sendo detectados casos em áreas consideradas silenciosas por décadas. Epizootias em primatas não humanos (NHPs) são considerados eventos sentinela para a detecção de casos humanos. É importante relatar eventos epizoóticos que podem ter impacto sobre o estado de conservação de espécies sensíveis. Descrevemos as epizootias, notificadas em NHPs no estado de São Paulo, Brasil, entre setembro de 2008 a agosto de 2009. Noventa e um eventos epizoóticos, envolvendo 147 animais, foram notificados em 36 municípios. As amostras foram obtidas a partir de 65 animais (44,2\%). A maioria das epizootias (46,6\%) foram registradas entre março e abril, no mesmo período no qual YF em que casos humanos ocorreram no estado. As amostras biológicas foram coletadas de animais encontrados mortos e enviadas ao Instituto Adolfo Lutz, em São Paulo. Duas amostras, coletadas em dois municípios, sem indicação para a vacinação de febre amarela, foram positivos para o vírus. Outros 48 animais foram associados com FA por vínculo clínicoepidemiológico com casos confirmados laboratorialmente. Devido a doença em humanos e NHPs terem ocorrido no mesmo período, a detecção do vírus em NHPs não funcionou como sentinela, mas ajudou no processo de delimitação de novas áreas de risco.

\section{ACKNOWLEDGMENTS}

We are grateful to Marcia Cristina T. Silva for supplying the cell culture and to Lucy T.A. dos Santos and Regina C.W.F Mozetic for supplying the suckling mice.

\section{REFERENCES}

1. Aguiar LM, Mellek DM, Abreu KC, Boscarato TG, Berbardi IP, Miranda JMD, et al. Sympatry between Alouatta caraya and Alouatta clamitans and the rediscovery of free ranging potential hybrids in Southern Brazil. Primates. 2007;48:245-8.

2. Anderson RM. Parasite pathogenicity and the depression of host population equilibria. Nature. 1979;279:150-2.

3. Bicca-Marques JL, Freitas DS. The role of monkeys, mosquitoes, and humans in the occurrence of a yellow fever outbreak in a fragmented landscape in south Brazil: protecting Howler monkeys is a matter of public health. Trop Conserv Sci. 2010;3:7889.

4. Bush AO, Lafferty KD, Lotz JM, Shostak AW. Parasitology meets ecology on its own terms: Margolis et al. J Parasitol. 1997;83:575-83.
5. Brés PLJ. A century of progress in combating yellow fever. Bull World Health Organ. 1986;64:775-86

6. Brito T, Siqueira AS, Santos RT, Nasser ES, Coimbra TL, Alves VA. Human fatal yellow fever. Immunohistochemical detection of viral antigens in liver, kidney and heart. Pathol Res Pract. 1992;188(1-2):177-81.

7. Bryant J, Wang H, Cabezas C, Ramírez G, Watts D, Russell K, et al. Enzootic transmission of yellow fever virus in Peru. Emerg Infect Dis. 2003;9:926-33.

8. Câmara FP, Gomes ALBB, Carvalho LMF, Castello LGV. Dynamic behavior of sylvatic yellow fever in Brazil (1954-2008). Rev Soc Bras Med Trop. 2011;44:297-9.

9. Deubel V, Huerre M, Cathomas G, Drouet MT, Wuscher N, Le Guenno B, et al. Molecular detection and characterization of yellow fever virus in blood and liver specimens of a non-vaccinated fatal human case. J Med Virol. 1997;53:212-7.

10. Formenty P, Boesch C, Wyers M, Steiner C, Donati F, Dind F, et al. Ebola virus outbreak among wild chimpanzees living in a Rain Forest of Côte d'Ivoire. J Infect Dis. 1999;179(Suppl 1):120-6.

11. Gregorin R. Taxonomia e variação geográfica das espécies do gênero Alouatta Lacépède (Primates, Atelidae) no Brasil. Rev Bras Zool. 2006;23:64-144.

12. Gubler DJ, Kuno G, Sather GE, Velez M, Oliver A. Mosquito cell cultures and specific monoclonal antibodies in surveillance for dengue viruses. Am J Trop Med Hyg. 1984;33:158-65

13. Hervé JP, Dégallier N, Travassos da Rosa APA, Sá Filho GC. A febre amarela silvestre no Brasil e os riscos de propagação urbana. Hiléia Méd. 1985;7:31-40.

14. Holzmann I, Agostini I, Areta JI, Ferreyra H, Beldomenico P, Di Bitetti MS. Impact of yellow fever outbreaks on two Howler monkey species (Alouatta guariba clamitans and A. caraya) in Misiones, Argentina. Am J Primatol. 2010;72:475-80.

15. Hutin YJF, Williams RJ, Malfait P, Pebody R, Loparev VN, Ropp SL, et al. Outbreak of human monkeypox, Democratic Republic of Congo, 1996-1997. Emerg Infect Dis. 2001;7:434-8.

16. IBGE - Instituto Brasileiro de Geografia e Estatística. Censo 2010. [Cited: 2011 June]. Available from: http://www.censo2010.ibge.gov.br

17. Igarashi A. Isolation of Singh's Aedes albopictus cell line clone sensitive to dengue and chikungunya virus. J Gen Virol. 1978;40:531-44.

18. Informe Técnico Centro de Vigilância Epidemiológica de São Paulo (CVE). 2009. Febre amarela silvestre no Estado de São Paulo, 2009. [Cited: 2011 June]. Available from: ftp://ftp.cve.saude.sp.gov.br/doc_tec/ZOO/Boletim_FASP171209.pdf

19. IUCN. IUCN Red List of Threatened Species. 2009. [Cited 2011 June]. Available from: www.iucnredlist.org

20. Lima MA, Romano-Lieber NS, Duarte AMRC. Circulation of antibodies against yellow fever virus in a simian population in the area of Porto Primavera Hydroelectric Plant, São Paulo, Brazil. Rev Inst Med Trop Sao Paulo. 2010;52:11-5.

21. Lima MR. Effects of infectious diseases and parasites on host populations and natural communities: the use of non-indigenous species (NIS) as models. Oecologia Australis. 2010;14:766-83.

22. McCallum H, Dobson A. Detecting disease and parasite threats to endangered species and ecosystems. Trends Ecol Evol. 1995;10:190-4.

23. Ministério da Saúde. Secretaria de Vigilância em Saúde. Manual de vigilância de epizootias em primatas não-humanos/Ministério da Saúde, Secretaria de Vigilância em Saúde - Brasília. 2005. [Cited 2011 June]. Available from: http://portal.saude. gov.br/portal/arquivos/pdf/epizootias.pdf 


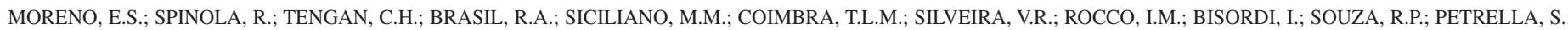
PEREIRA, L.E.; MAEDA, A.Y.; SILVA, F.G. \& SUZUKI, A. - Yellow fever epizootics in non-human primates, São Paulo State, Brazil, 2008-2009. Rev. Inst. Med. Trop. Sao Paulo, 55(1): 45-50, 2013.

24. Ministério da Saúde/Secretaria de Vigilância em Saúde. Emergências em Saúde Pública de Importância Nacional (ESPIN) de Febre Amarela Silvestre em São Paulo e no Rio Grande do Sul e a Situação Epidemiológica Atual no Brasil (2008/2009). 2009. [Cited: 2011 June]. Available from: http://portal.saude.gov.br/portal/arquivos/ pdf/boletim_febre_amarela_09_12_09.pdf

25. Ministério da Saúde - Secretaria de Vigilância em Saúde. Guia de Vigilância Epidemiológica. Série A. Normais e Manuais Técnicos. Brasília - DF. 2009. [Cited 2011 June]. Available from: http://bvsms.saude.gov.br/bvs/publicacoes/Guia_Vig_ Epid_novo2.pdf

26. Ministério da Saúde, Secretaria de Vigilância em Saúde. Boletim Eletrônico Epidemiológico, Situação Epidemiológica das Zoonoses de Interesse à Saúde Pública. 2009. [Cited: 2011 June]. Available from: http://portal.saude.gov.br/portal/arquivos/ pdf/ano09_n01_sit_epidemiol_zoonoses-br.pdf

27. Moreno ES, Rocco IM, Bergo ES, Brasil RS, Siciliano MM, Suzuki A, et al. Reemergence of yellow fever: detection of transmission in the State of São Paulo, Brazil, 2008. Rev Soc Bras Med Trop. 2011;44:290-6.

28. Ott-Joslin JE. Viral diseases in nonhuman primates. In: Fowler M. Zoo and wild animal medicine. Philadelphia: W.B. Saunders; 1986. p. 674-97.

29. Rawlins SC, Hull B, Chadee DD, Martinez R, Lemaitre A, James F, Webb L. Sylvatic yellow fever activity in Trinidad, 1988-1989. Trans R Soc Trop Med Hyg. 1990;84:142-3.

30. Rede Nacional de Combate ao Tráfico de Animais Silvestres 2008. $1^{\circ}$ Relatório Nacional sobre o Tráfico de Fauna Silvestre. [Cited: 2011 June]. Available from: www.renctas.org.br
31. Richter CB, Lehner NDM, Henrickson RV. Primates. In: Fox JG, Cohen BJ, Loew FM, editors. Laboratory animal medicine. San Diego: Academic Press; 1984. p. 287-383.

32. Rifakis PM, Benitez JA, Pineda JP, Rodriguez-Morales A. Epizootics of yellow fever in Venezuela (2004-2005) an emerging zoonotic disease. Ann N Y Acad Sci. 2006;1081:57-60.

33. Rylands AB, Mittermeier RA. The diversity of the new world primates (Platyrrhini): an annotated taxonomy. In: Garber PA, Estrada A, Bicca-Marques IC, Heymann EK, Strier KB, editors. South American primates: comparative perspectives in the study of behavior, ecology, and conservation. New York: Springer; 2009. p 23-54.

34. Sabbatini E, Bisgaard K, Ascani S, Poggi S, Piccioli M, Ceccarelli C, et al. The Envision $^{\mathrm{TM}}+$ System: a new immunohistochemical method for diagnostics and research. Critical comparison with the APAAP, ChemMate ${ }^{\mathrm{TM}}$, CSA, LABC and SABC techniques. J Clin Pathol. 1998;51:506-11.

35. Souza RP, Foster PG, Sallum MAM, Coimbra TLM, Maeda AY, Silveira VR, et al Detection of a new yellow fever virus lineage within the South American genotype I in Brazil. J Med Virol. 2010;82:175-85.

36. Thompson SA, Hilliard JK, Kittel D, Lipper S, Giddens WE, Black DH, et al Retrospective analysis of an outbreak of B virus infection in a colony of DeBrazza's monkeys (Cercopithecus neglectus). Comparative Med. 2000;50:648-57.

37. Vasconcelos PFC. Febre amarela. Rev Soc Bras Med Trop. 2003;36:275-93.

Received: 27 March 2012

Accepted: 16 July 2012 